\title{
Pelatihan Pembuatan Video Pembelajaran Online Bagi Mahasiswa Calon Guru Pendidikan Agama Islam Sebagai Antisipasi Mewabahnya Covid 19 Sekolah Tinggi Ilmu Tarbiyah Syamsul Ma'arif Bontang Tahun 2020/2021
}

\author{
Muh. Ihsan \\ Dosen Sekolah Tinggi Ilmu Tarbiyah Syamsul Ma'arif Bontang, Indonesia \\ Jl. Cut Nyak Dien No.108, Bontang Kuala, Bontang Utara, Kota Bontang, Kalimantan Timur 75325 \\ iccanrichtv@gmail.com
}

\begin{abstract}
Abstrac
Education is a central activity in advancing and developing the potential of students, which in this case are prospective students of Islamic religious education teachers at the Bontang Tarbiyah College of Sciences. With the outbreak of covid-19, educational activities have changed very significantly related to the implementation of learning activities from face to face to online learning. With these changes, it automatically forces education providers from basic to high levels to be able and creative in developing the online learning system. So that the results of online learning can be achieved properly, it is necessary to carry out training activities not only making learning videos but more importantly how a lecturer or teacher or student as a prospective teacher is able to use internet equipment such as using computers, using online learning tools, making online learning tools and the preparation of online learning materials and the process of implementing online learning. All of this is expected to produce the quality of education as expected.
\end{abstract}

Keywords: Training, video making, learning, online, a prospective teacher.

\begin{abstract}
Abstrak
Pendidikan merupakan kegiatan sentral dalam memajukan dan mengembangkan potensi peserta didik yang dalam hal ini adalah mahasiswa calon guru pendidikan agama islam Sekolah Tinggi Ilmu Tarbiyah Bontang. Dengan mewabahnya covid 19, maka kegiatan pendidikan berubah secara sangat signifikan terkait dengan pelaksanaan kegiatan pembelajaran dari tatap muka ke pembelajaran secara online atau daring. Dengan perubahan tersebut, maka secara otomatis memaksa penyelenggara pendidikan mulai dari tingkat dasar sampai tingkat tinggi agar mampu dan kreatif dalam mengembangkan system pembelajaran online tersebut. Agar hasil pembelajaran online tersebut dapat tercapai dengan baik, maka perlu dilakukan kegiatan pelatihan tidak hanya pembuatan video pembelajaran tetapi lebih utama bagaimana seorang dosen atau guru ataupun mahasiswa sebagai calon guru mampu menggunakan peralatan internet seperti penggunaan computer, penggunaan alat pembelajaran online, pembuatan perangkat pembelajaran online, dan penyusunan materi pembelejaran online dan proses pelasanakaan pembelajaran online. Kesemua itu diharapkan dapat menghasilkan kualitas pendidikan sesuai dengan yang diharapkan.
\end{abstract}

Keywords: Pelatihan, pembuatan video, pembelajaran, online, calon guru

\section{PENDAHULUAN}

Program studi pendidikan agama islam merupakan wahana bagi pengembangan potensipotensi yang dimiliki oleh setiap mahasiswa. Dengan demikian, program studi pendidikan agama islam sebagai bagian integral dari pendidikan tinggi yang ada, memiliki peran yang sangat penting di dalam menanamkan nilai-nilai, transpormasi ilmu pengetahuan dan pengembangan kreativitas serta pengalaman-pengalaman kerja atau organisasi yang dapat digunakan oleh mahasiswa calon guru pendidikan agama islam tersebut sebagai modal dasar di dalam menata dan sekaligus membentuk peserta didik yang dibinanya menjadi insan kamil yang lebih cerdas, kreatif, dan memiliki nilai-nilai kepribadian yang sudah tertanam secara kuat dan kokoh, kelak setelah pendidikan tinggi yang ditempuhnya selesai. Nana Sudjana (2004). 
Untuk mencapai gagasan tersebut di atas, maka jauh sebelumnya mahasiswa program studi pendidikan agama islam sebagai calon guru pendidikan agama islam sangat perlu dibekali dengan pengetahuan yang memadai mengenai tatacara pelaksanaan penanaman nilai-nilai, transpormasi ilmu pengetahuan, pengembangan kreativitas dan pengalaman kerja yang relevan yang akan disampaikan kepada peserta didik yang dibinanya kelak. Namun hal ini hanya dapat dilakukan secara seksama apabila dalam kondisi normal dan tanpa halangan, rintangan dan tantangan apapun yang dihadapi. Santyasa, Wayan, (2009)

Tentu saja berbeda keadaannya apabila kondisi yang dihadapi dalam keadaan tidak normal seperti biasa. Dalam kaitan ini perlu ditanggapi secara serius mengenai wabah yang melanda seluruh negeri saat ini, yaitu penyebaran wabah covid 19 yang memaksa seluruh elemen masyarakat untuk tidak melaksanakan seluruh rangkaian kegiatan seperti hari-hari normal sebelumnya. Artinya bahwa dunia pendidikan pun dipaksa untuk tiddak melaksanakan pendidikan secara tatap muka di sekolah. Oleh karena itu dunia pendidikan dipaksa oleh keadaan agar lebih dulu merumahkan seluruh peserta didiknya mulai dari tingkat dasar sampai kepada pendidikan tingkat tinggi. Hal ini dilematis, tetapi dalam konteks pendidikan, maka mewabahnya virus corona tersebut tidak dapar dijadikan alasan agar pendidikan tersebut tidak melaksanakan. Justru dengan mewabahnya covid 19 ini, setiap elemen masyarakat yang ada termasuk mahasiswa program studi pendidikan agama islam harus mampu menata kreativitas diri dalam rangka menghadapi berbagai macam permasalahan yang timbul, baik di kalangan masyarakat secara umum maupun di dalam lingkungan perguruan tinggi dimana mahasiswa calon guru pendidikan agama islam tersebut menimba ilmu. Tarsito Sofwan Amri, et.al. (2010)

Kondisi tersebut dapat dilihat melalui keadaan kampus dimana penulis mengabdikan diri yang sejak tanggal 16 maret 2020 sampai sekarang ini sudah merumahkan mahasiswanya.

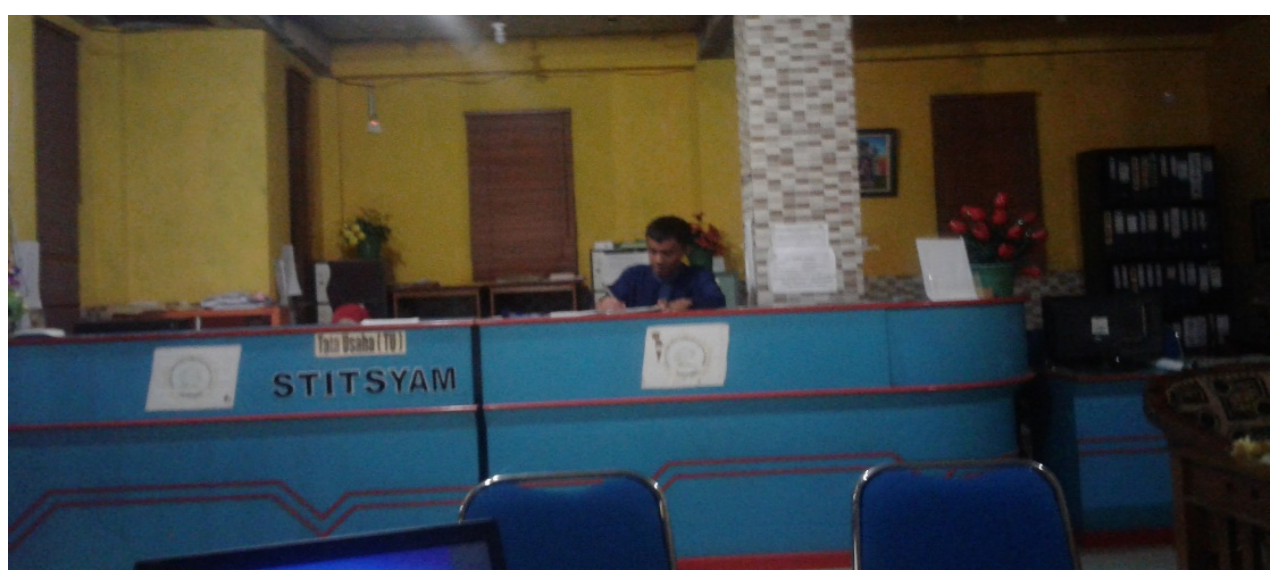

Gambar 1. Keadaan Kantor

Meskipun pelayanan administrasi tetap diberikan oleh kampus Sekolah Tinggi Ilmu Tarbiyah Bontang, namun keadaannya menjadi sepi bahkan nyaris tidak ada pelayanan sama sekali. Hal ini dilakukan karena mengikuti anjuran dan protocol kesehatan yang dihimbaukan oleh pemeritah mulai dari tingkat pusat sampai tingkat pemerintah tingkat kabupaten/kota. Kondisi tampak sebagaimana gambar di atas. Pembatasan pelayanan administrasi secara tatap muka berlangsung sejak tanggal 16 Maret 2020 sampai sekarang. Demikian juga dengan pelaksanaan perkuliahan yang selama ini dilakukan secara tatap muka, namun setelah virus covid-19 mewabah segalanya menjadi berubah, Wikipedia (2019). Perkuliahan dilaksanakan secara online dengan fasilitas perkuliahan yang menggunakan jaringan internet melalui zoom 
cloud meeting, google meeting dan lain sebagainya. Sehingga dengan demikian ruang perkuliahan yang ada menjadi kosong sama sekali, seperti tampak pada gambar berikut ini:

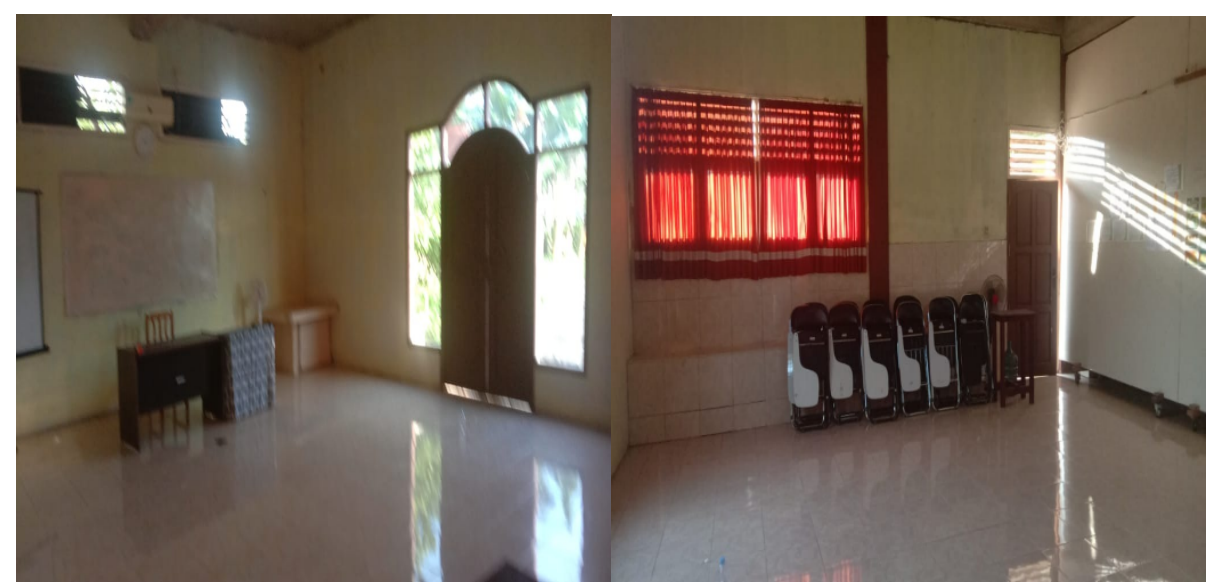

Gambar 2. Keadaan ruang perkuliahan

Dalam rangka menindaklanjuti permasalahan mengenai mewabahnya covid 19 tersebut, maka pihak tim manajemen Sekolah Tinggi Ilmu Tarbiyah Syamsul Ma'arif Bontang memberikan kesempatan seluas-luasnya kepada dosen dan mahasiswa calon guru pendidikan agama islam untuk secara serius ikut terlibat di dalam mengatasi atau mengantidipasi mewabahnya covid 19 tersebut sesuai keahlian dan kemampuan yang dimiliki masing-masing bersangkutan. Hal ini, penulis manfaatkan secara baik dalam rangka melatih mahasiswa calon guru pendidikan agama islam yang bertujuan untuk mengembangkan kreativitas pembelajaran secara online

\section{METODE PELAKSANAAN}

Pelaksanaan kegiatan pelatihan pembuatan video pembelajaran dalam rangka mengantisipasi mewabahnya covid-19 tersebut berlangsung selama dua (2) hari dengan keterangan: hari pertama dilaksanakan secara tatap muka dengan tetap memperhatikan protocol kesehatan; menjaga jarak, mencuci tangan dan lain sebagainya. Kehadiran peserta pada hari pertama ini dibatasi sampai 10 orang peserta saja. Kemudian hari kedua dilaksanakan secara online dengan dihadiri oleh peserta sebanyak 20 orang. Hal ini bertujuan disamping mempraktekkan hasil pelatihan tatap muka pada hari pertama, juga diupayakan melakukan perbaikan-perbaikan demi penyempurnaan hasil dari pembuatan video pembelajaran tersebut. Selain itu, berikut ini diuraikan juga mengenai pelaksanaan kegiatan pelatihan tersebut yang berkenaan dengan:

A. Lokasi Kegiatan

Lokasi pelaksanaan kegiatan pelatihan pembuatan video pembelajaran berada di jalan Cut Nyak Dien Gg Kerikil 8 RT 13 Nomor 108 Kelurahan Bontang Kuala Kecamatan Bontang Selatan Kota Bontang.

B. Jadwal Pelaksanaan kegiatan

Jadwal pelaksanaan kegiatan diuraikan sebagaimana table pelaksanaan pelatihan pembeuatan video pembelajaran berikut ini: 
Tabel 1. Jadwal Kegiatan Pelatihan

\begin{tabular}{|c|c|c|c|c|}
\hline No & $\begin{array}{l}\text { Uraian } \\
\text { Kegiatan }\end{array}$ & Materi Pelatihan & $\begin{array}{l}\text { Alat yang } \\
\text { digunakan }\end{array}$ & $\begin{array}{c}\text { Pesert } \\
\mathrm{a}\end{array}$ \\
\hline 1 & $\begin{array}{l}\text { Hari } \\
\text { Pertama } \\
\text { Sabtu, } 11 \\
\text { April } 2020\end{array}$ & $\begin{array}{l}\text { Pelaksanaan pelatihan pembuatan video } \\
\text { pembelajaran secara tatap muka dengan tetap } \\
\text { memperhatikan protocol kesehatan, Materi: } \\
\text { 1. Pengenalan terhadap aplikasi pembelajaran } \\
\text { yang digunakan, aplikasi power point yang } \\
\text { diubah menjadi video } \\
\text { 2. Pembuatan perangkat pembelajaran online } \\
\text { seperti absensi, silabus, RPP dan lain-lain. } \\
\text { 3. Cara penyajian materi dengan } \\
\text { menggunakan power point yang menarik } \\
\text { minat belajar peserta didik } \\
\text { 4. Cara Membuat Video Pembelajaran dengan } \\
\text { menggunakan aplikasi power point dan } \\
\text { aplikasi fhotos }\end{array}$ & $\begin{array}{l}\text { Fasilitas } \\
\text { Wifi gratis } \\
\text { a.Laptop } \\
\text { b.Microsoft } \\
\text { word } \\
\text { c. Excell } \\
\text { d.Power } \\
\text { Point } \\
\text { e.Power } \\
\text { point } \\
\text { f. Project } \\
\text { Video }\end{array}$ & $\begin{array}{l}10 \\
\text { orang }\end{array}$ \\
\hline 2 & $\begin{array}{l}\text { Hari kedua } \\
\text { Ahad, } 12 \\
\text { April } 2020\end{array}$ & $\begin{array}{l}\text { Praktek Penggunaan video pembelajaran, } \\
\text { terutama cara mengunggah video ke youtube } \\
\text { dan membaginya ke whatsapp }\end{array}$ & $\begin{array}{l}\text { a. Laptop } \\
\text { b. Hp } \\
\text { c. Zoom } \\
\text { cloud } \\
\text { meeting } \\
\text { d. Youtube }\end{array}$ & $\begin{array}{l}20 \\
\text { orang }\end{array}$ \\
\hline
\end{tabular}

C. Latar Belakang Peserta

Peserta pelatihan cara membuat video pembelajaran adalah mahasiswa program studi pendidikan agama islam yang sedang menempuh kuliah di Sekolah Tinggi Ilmu Tarbiyah Syamsul Ma'arif Bontang. Mereka yang terlibat terdiri dari mahasiswa semester dua sampai dengan semester delapan yang diambil secara acak dari masing-masing semester. Mahasiswa yang terlibat inilah kemudian diharapkan dapat menjadi pembelajar kepada teman-teman mahasiswanya yang lain. Oleh karena itu, pelatihan pembuatan video pembelajaran ini untuk membekali mahasiswa karena pertama, mereka adalah calon guru pendidikan agama islam yang tidak boleh ketinggalan dalam hal pemanfaatan teknologi informasi dan komunikasi yang menggunakan perangkat internet. Kedua, mereka juga rata-rata sudah mengajar di sekolah-sekolah atau madrasah yang ada di Kota Bontang.

\section{HASIL DAN PEMBAHASAN}

\section{A. Hasil Pelatihan}

Servey kepuasan mahasiswa sebagai calon guru pendidikan agama islam terhadap pelatihan pembuatan video pembelajaran dilaksanakan dua kali selama kegiatan pelatihan berlangsung, yaitu sebelum pelaksanaan dan setelah pelatihan dilaksanakan. Oleh karena itu dapat diketahui bahwa hasil pelaksanaan survei hasil pelatihan mahasiswa calon guru pendidikan agama islam terhadap pelaksanaan kegiatan pelatihan pembuatan video pembelajaran, dan tindak lanjutnya. Bahwa pemahaman di kalangan mahasiswa calon guru pendidikan agama islam mengenai pelaksanaan dan hasil yang dicapai yang diaplikasi di 
lingkungan Sekolah Tinggi Ilmu Tarbiyah Syamsul Ma'arif Bontang sebagaimana perhitungan chart berikut ini:
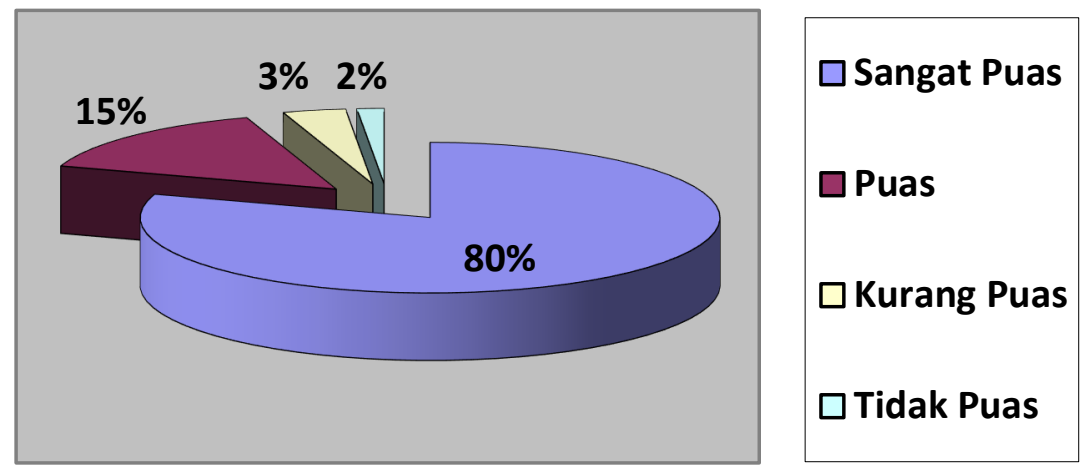

Gambar 3. Kepuasan Peserta Pelatihan

Berdasarkan pada perhitungan hasil survey yang dilakukan dua kal selama pelatihan berlangsung dapat diketahui bahwa sebanyak $80 \%$ mahasiswa calon guru PAI merasa sangat puas terhadap kegiatan pelatihan pembuatan video pembelajaran tersebut. Artinya, respon sebesar itu menunjukkan bahwa pelatihan pembuatan video pembelajaran sangat bermanfaat bagi mereka. Dan sebanyak 15\% mahasiswa calon guru PAI merasa puas dengan dilaksanakannya kegiatan pelatihan pembuatan video pembelajaran tersebut. Serta sebanyak $3 \%$ dari mahasiswa yang merasa kuarang puas dan 2 persen saja yang merasa tidak puas. Artinya, dapat disimpulkan bahwa hasil pelatihan tersebut secara keseluruhan berhasil guna bagi mahasiswa calon guru PAI yang mengikuti pelatihan dalam rangka upaya antisipatif terhadap mewabahnya virus covid-19 tersebut. Dengan demikian mahasiswa calon guru PAI sudah terbekali pengetahuan dan kreativitas pembuatan video pembelajaran yang kelak dapat digunakan untuk melaksanakan pembelajaran online di mana mereka mengabdikan diri masing-masing.

B. Pembahasan

Sebagaimana telah diuraikan bahwa pelatihan ini mengangkat tema yaitu pelatihan pembuatan video pembelajaran bagi mahasiswa calon guru PAI sebagai upaya antisipatif terhadap mewabahnya virus covid 19 Sekolah Tinggi Ilmu Tarbiyah Syamsul Ma'arif Bontang Tahun 2020/2021. Kiranya sudah tergambar langkah-langkah strategi pelatihan yang dapat digunakan yang melibatkan mahasiswa calon guru PAI dalam mengefektifkan system pembelajaran online tersebut. Langkah-langkah tersebut mencakup: (a) Pengenalan terhadap aplikasi pembelajaran yang digunakan, seperti aplikasi power point yang diubah menjadi video yang digagas dalam kerangka temuan sebagai sebuah solusi. (b) Pembuatan perangkat pembelajaran online seperti absensi, RPP, silabus,dan lain-lain. (c) Cara penyajian materi dengan menggunakan power point yang menarik minat belajar peserta didik dan (d) Cara Membuat Video Pembelajaran dengan menggunakan aplikasi power point dan aplikasi fhotos. (e) Praktek Penggunaan video pembelajaran, terutama cara mengunggah video ke youtube dan membaginya ke whatsapp. 
Langkah-langkah pelatihan pembuatan video pembelajaran yang ditempuh sebagai upaya antisipatif dan mengefektifkan system pembelajaran online pada masa pandemi covid 19, antara lain:

a. Pengenalan terhadap aplikasi pembelajaran

Pertama yang dimaksud dengan aplikasi pembelajaran adalah berupa peralatan yang dapat digunakan dalam melaksanakan pembelajaran secara daring atau online. Pengenalan tersebut penting untuk diketahui secara baik agar pada saat menggunakan aplikasi tersebut peserta pelatihan tidak mengalami kesulitan dalam menggunakan dan mengoperasikannya. Seperti aplikasi power point, peserta harus mengetahui secara baik kegunaan mengenai: (1) presentation chart, (2) home, (3) insert, (4) design (5) new slide, (6) transitions (7) new tab, (8) slide show dan lain sebagainya. Apabila perangkatperangkan ini sudah dipahami dengan baik kegunaannya, maka sudah barang tentu dapat pula menaplikasikannya dalam kegiatan pembelajarannya. Seperti tampak pada gambar berikut ini:

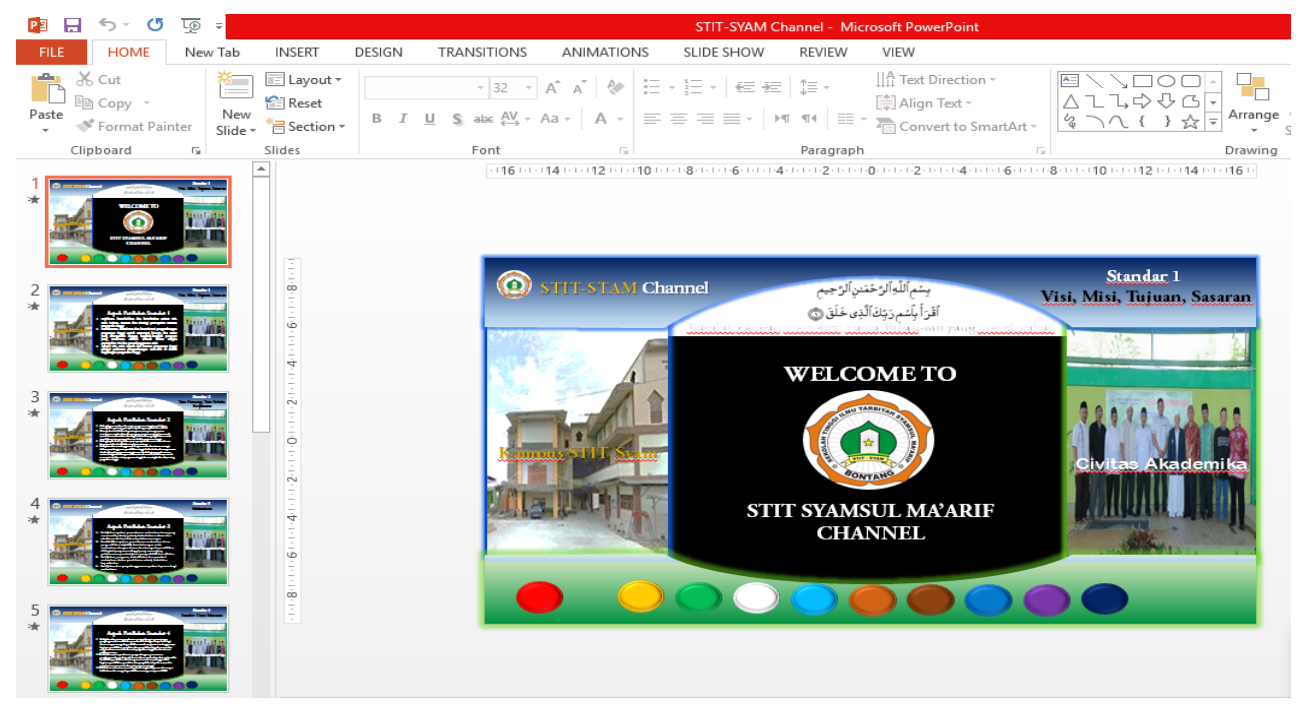

Gambar 4. Contoh Aplikasi power point

b. Pembuatan perangkat pembelajaran online

Pembuatan perangkat pembelajaran online atau daring bukanlah suatu kesulitan untuk dilakukan oleh peserta pelatihan. Sebab rata-rata dari peserta pelatihan tersebut sudah mengabdikan diri mereka masing-masing di suatu sekolah yang tentu saja sudah mengetahun cara membuat dan menyusun perangkat pembelajaran tersebut. Yang perlu pembekalan dan arahan dalam hal ini yang berkenaan dengan bagaimana mengunggahnya ke dalam jaringan internet. Sehingga dapat dikatakan bahwa apabila perangkat pembelajaran sudah tersedia, maka langkah selanjutnya adalah membuka filefile tersebut di laptop yang ada lalu membuka internet untuk tujuan mengunggah file perangkat pembelajaran tersebut melalui aplikasi internet yang digunakan seperti zoom cloud meeting. Berikut ini merupakan suasana pelatihan membuat perangkat pembelajaran online yang diikuti oleh 10 orang peserta, sebagaimana gambar berikut ini: 


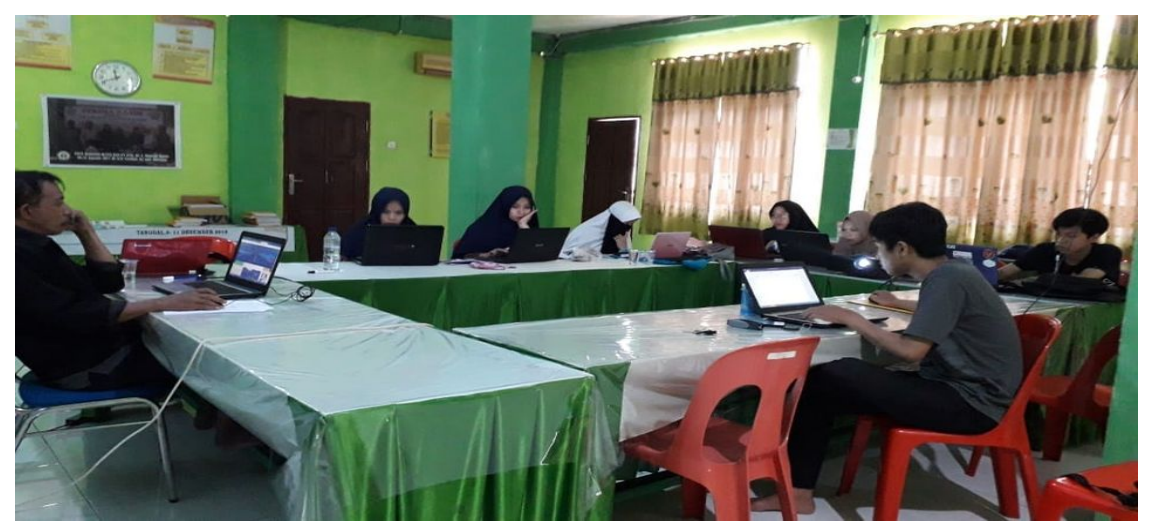

Gambar 5. Suasana Pembuatan Perangkat Pembelajaran Online

c. Penyajian Materi dengan Menggunakan Power Point

Sebelum melakukan penyajian materi melalui internet, maka terlebih dahulu mempersiapkan materi pelajaran yang akan diasjikan dengan menggunakan power point. Misalnya materi pelajaran Aqidah Akhlak. Materi tersebut disusun secara menarik dengan menggunakan perangkat-perangkat power point yang sudah tersedia, seperti penggunaan slide show, penggunaan font, gambar, warna, sehingga tayangan power point tersebut tidak monoton dan justru menarik minat peserta didik untuk lebih serius mengikuti pembelajaran online yang dilaksanakan oleh guru bersangkutan. Peserta pelatihan diarahkan dengan menggunakan cara ini.

d. Membuat Video Pembelajaran dengan menggunakan aplikasi power point dan aplikasi fhotos

Video pembelajaran pada dasarnya bukanlah sesuatu yang sulit untuk dibuat, sebab sarana yang dapat digunakan untuk membuatnya sudah tersedia dengan baik dalam computer atau laptop. Misalnya membuat video dengan menggunakan power point, hal ini mudah saja dilakukan. Caranya adalah menyediakan materi pelajaran yang sudah disusun secara baik dan menarik melalui power point kemudian power point yang memuat materi pelajaran tersebut diubah dengan pertama membiarkan aplikasi power point tersebut terbuka, lalu menklik file yang terterah di perambaan, selanjutnya menggulir mouse sampai ketemu dan mengklik kata export setelah itu mengklik create a video lalu memilih computer HD displays dan use recorder timing and narrations lalu yang terakhir mengklik create video. Lalu menunggu hingga proses pembuatan video oleh system computer selesai. Aplikasi fhotos juga demikian adanya. Bedanya kalau power point peserta pelatihan harus menyediakan materi pelajaran dengan menggunakan aplikasi power point terlebih dahulu, sementara aplikasi fhotos menyedikan data visul atau gambar-gambar pembelajaran yang digunakan lalu gambar tersebut diubah dengan menyimpannya dengan menggunakan aplikasi fhotos. Setelah itu tunggu beberapa saat hingga proses pembuatan video selesai diproses oleh system computer selesai.

e. Praktek Penggunaan video pembelajaran

Penggunaan video pembelajaran merupakan langkah tepat yang dapat digunakan untuk menunjang peningkatan kualitas pembelajaran yang dilaksanakan oleh guru agar tetap melangsungkan program pendidikan meskipun virus covid-19 mewabah dalam rangka membina peserta didiknya. Video pembelajaran tentu saja tidak serta merta jadi begitu saja tanpa didahului oleh serangkaian kegiatan dalam membuatnya. Misalnya pelatihan yang secara terencana yang dilaksanakan secara konsisten agar video 
pembelajaran tersebut dapat dimanfaatkan oleh yang berkepentingan, terutama peserta didik. Usman Basyiruddin, (2002).

Praktek penggunaan video pembelajaran ini dilaksanakan segera setelah peserta mengikuti serangkaia pelatihan yang mendahuluinya. Selanjutnya, praktek ini dapat terealisasi dengan baik apabila ditunjang dengan fasilitas-fasilitas yang sesuai, mudah dijangkau dan murah harganya. Misalnya ketersediaan jaringan internet atau wifi yang dapat digunakan secara leluasa oleh penggunanya. Demikian pula dengan ketersediaan aplikasi pembelajaran online atau daring yang sudah terinstall secara baik di dalam computer atau laptop maupun handphone. Seperti aplikasi whatsapp, zoom cloud meeting, google meeting dan lain aplikasi lain yang relevan yang memungkinkan untuk digunakan dalam kegiatan pembelajaran online atau daring. BDK Kemenag, (2021)

Praktek pembelajaran online dengan menggunakan jaringan internet secara langsung dapat dilihat pada tayangan gambar berikut ini:

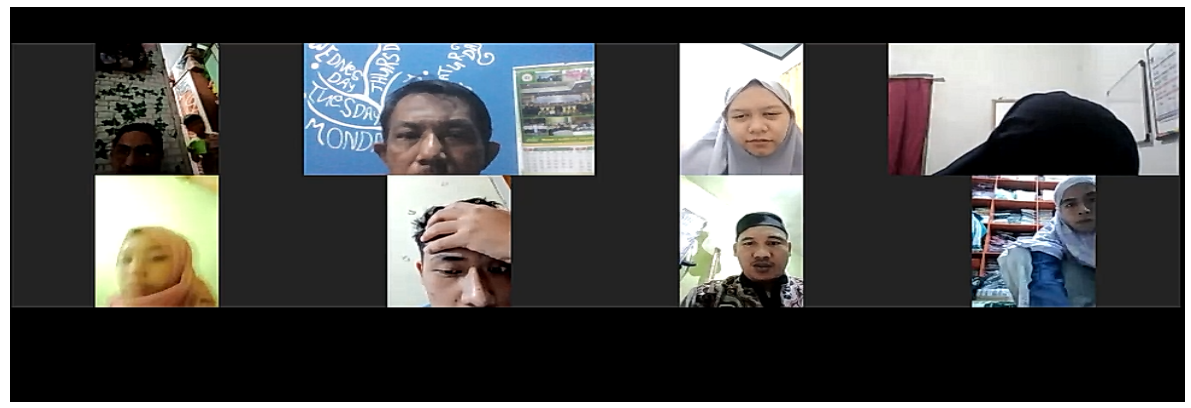

Gambar 6. Absensi Awal Peserta Pembelajaran Online

Absensi awal perlu dilakukan untuk mengetahui apakah peserta telah hadir dalam forum zoom meeting cloud yang sudah dibagikan linknya melalui whatsapp yang ada di handphone atau laptop masing-masing. Mengingat guru tidak dapat melihat langsung secara fisik kehadiran peserta didik segera setelah pembelajaran akan dimulai. Dalam kaitan ini guru perlu memastikan kehadiran peserta didik dengan menampakkan wajah mereka masing-masing secara langsung melalui tayangan video. Tujuannya adalah untuk mempermudah guru dalam mengabsen kehadiran peserta. Lalu setelah itu melakukan apersepsi, membaca do'a dan lain sebagainya. Hal ini dilakukan sebagaimana layaknya pelaksanaan pembelajaran tatap muka. BDK Kemenag, (2021)

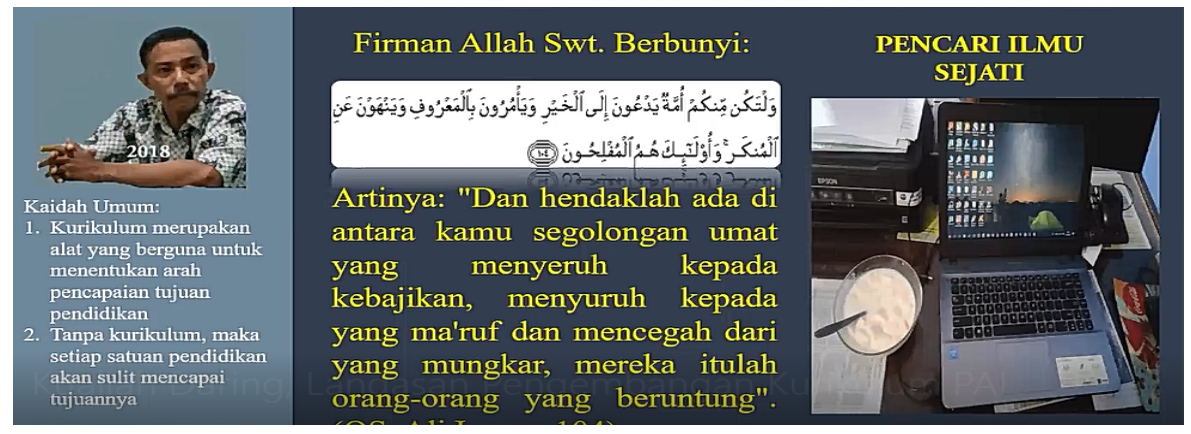

Gambar 7. Praktek Penyampaian Materi Pembelajaran Online

Materi pembelajaran disajikan segerah setelah kegiatan awal dilakukan seluruhnya. Gambar 5 di atas menujukkan bahwa materi tersebut disampaikan sesuai dengan materi yang dikemas sedemikian rupa melalui aplikasi power point atau lainnya. Power point 
dibuat semenarik mungkin agar peserta didik yang mengikuti jalannya proses pembelajaran tersebut focus perhatiannya tertuju kepada materi yang disajikan saat itu.

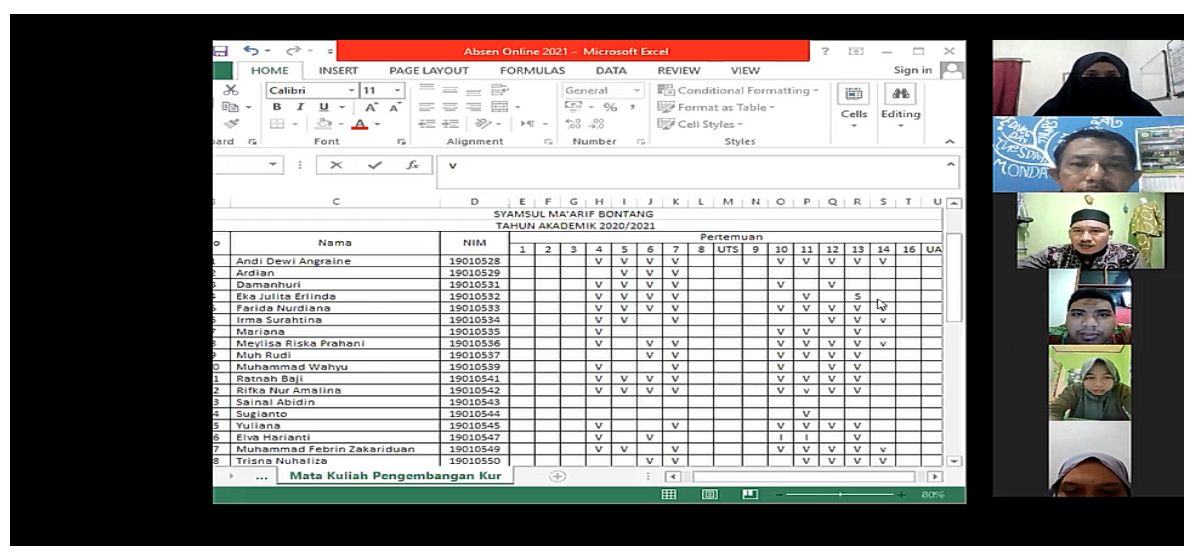

Gambar 8. Absensi Akhir Pembelajaran Online

Absensi akhir juga perlu dilakukan untuk mengetahui apakah peserta telah hadir dalam forum zoom meeting cloud benar-benar ada dan mengikuti secara seksama jalannya proses pembelajaran online. Absensi akhir bertujuan untuk mengontrol kehadiran peserta mulai dari awal hingga akhir proses pembelajaran daring. Dalam kaitan ini guru perlu memastikan kehadiran peserta didik dengan menampakkan wajah mereka masing-masing secara langsung melalui tayangan video. Tujuannya adalah untuk mempermudah guru dalam mengabsen kehadiran peserta. Pusdatin kemendikbud, (2020)

f. Hambatan yang dihadapi

Hambatan-hambatan yang dihadapi dalam pelaksanaan kegiatan pelatihan pembuatan video pembelajaran, antara lain terkait dengan:

1. Fasilitas wifi

Kecukupan dan kapasitas wifi yang memang harus disediakan untuk mendukung pelaksanaan pembelajaran online. Tanpa kecukupan kapasitas wifi tersebut, maka pelaksanaan pembelajaran online akan sulit dicapai secara maksimal.

2. Gangguan jaringan internet

Jaringan internet bukanlah suatu perangkat yang keberadaannya tanpa hambatan. Jaringan internet tersebut justru acapkali mengalami gangguan pada saat dalam penggunaannya. Apatahlagi bila menggunakan zoom cloud meeting yang gratis. Fasilitas ini sangat terbatas waktunya. Hanya berkisar 40 menit saja yang bisa digunakan dalam melangsungkan pembelajaran online. Demikian juga dengan penggunaan video pembelajaran akan mengalami gangguan sebagaimana sudah diutarakan di atas.

3. Biaya mahal bagi peserta dan Paket data kurang memadai

Video pembelajaran online juga memiliki kendala dari segi paket data. Apatahlagi bagi yang menggunakan handphone. Dan biaya paket data tersebut bukan barang murah. Sekali online menggunakan paket data $2 \mathrm{gb}$, dengan harga Rp.35.000,- jadi dalam waktu satu bulan biaya untuk paket data tersebut sebesar Rp. 700.000,-

4. Cuaca tidak mendukung

Dalam kaitan ini, acapkali saat pembelajaran dengan menggunakan video berlangsung kemudian hujan deras turun tentu menghasilkan suatu yang lebih besar. Sehingga suara yang digunakan untuk kegiatan pembelajaran juga harus lebih dari suara yang dihasilkan oleh turunnya hujan tersebut. 
5. Ketersediaan sumber daya listrik

Kehidupan modern saat ini, manusia pada umumnya tidak terlepas dari listrik. Bahkan nyaris semuanya menggunakan listrik. Termasuk dalam kegiatan pembelajaran online tersebut. Apabila sumber daya listrik ini tidak tersedia dengan baik maka pembelajaran online akan mengalami hambatan dari segi penerangan. Handphone dicash menggunakan listrik, demikian juga dengan laptop.

g. Tindak lanjut

Bahwa hasil pelatihan mengenai pembuatan video pembelajaran terlihat bahwa mahasiswa calon guru pendidikan agama islam yang mengikuti kegiatan pelatihan yang dilaksanakan selama dua hari tersebut pada dasarnya membuahkan hasil. Hal ini menunjukkan bahwa pelatihan pembuatan video pembelajaran yang dilaksanakan di Sekolah Tinggi Ilmu Tarbiyah STIT Syamsul Ma'arif Bontang diasumsikan dapat digunakan untuk melangsungkan pembelajaran online sekaligus sebagai upaya antisipatif terhadap mewabahnya virus covid 19 tersebut.

\section{KESIMPULAN}

Seperti telah dijelaskan bahwa pendidikan merupakan sentral dalam mengembangan potensi peserta didik. Peserta didik dalam kaitan ini juga termasuk mahasiswa yang sedang menimba ilmu pendidikan agama islam di Sekolah Tinggi Ilmu Tarbiyah Syamsul Ma'arif Bontang. Agar kualitas pendidikan dapat tercapai dengan baik maka perlu pembekalan tidak hanya yang berkaitan dengan penguasaan ilmu pengetahuan teoritis belaka melainkan juga krativitas-kreativitas yang dapat digunakan untuk menunjang berlangsungnya kegiatan pembelajaran, baik yang dilaksanaan secara tatap muka maupun secara daring atau online.

Bahwa pelatihan dalam pembuatan video pembelajaran yang dilaksanakan selama dua hari tersebut membuahkan hasil sesuai harapan, meskipun memang masih perlu pembenahan dan peningkatan, baik dalam hal pembuatannya, penggunaannya maupun pembenahan terkait dengan hambatan-hambatan yang mungkin dihadapi. Hasil tersebut dapat dilihat dengan maraknya muncul video pembelajaran yang dirancang oleh mahasiswa calon guru dengan berbagai model dan caranya masing-masing, baik yang sudah alumni mapun yang masih aktif. Minimal ada rangsangan dan semangat untuk mengembangkan potensi paedagogik kearah yang lebih baik.

\section{DAFTAR PUSTAKA}

Nana Sudjana. (2004). Teknologi Pengajaran. Bandung: Sinar Baru Algensindo Santyasa, Wayan, (2009) "Metode Penelitian Pengembangan dan Teori Pengembangan Modul", dalam http://maskursmkn.files.wordpress.com/2009/07/teori modul.pdf

Tarsito Sofwan Amri, et.al.(2010). Kontruksi Pengembangan Pembelajaran. Jakarta: Prestasi Pustaka

Usman Basyiruddin. (2002). Metodologi Pembelajaran Agama Islam. Jakarta: Ciputat Pers.

https://id.m.wikipedia.org/wiki/Penyakit koronavirus_2019 diakses pada hari Rabu, tanggal 18 Pebruari 2021 pada jam 13.26 Wita

https://jagokata.com/arti-kata/kearifan.html diakses pada hari Ahad, tanggal 20 Pebruari 2021 jam 9.00 Wita. 
https://pusdatin.kemdikbud.go.id/pembelajaran-online-di-tengah-pandemi-covid-19tantangan-yang-mendewasakan/ diakses pada hari selasa, 23 Juni 2021 jam 13.00 wita

https://bdkjakarta.kemenag.go.id/berita/efektivitas-pembelajaran-daring-di-masapandemi-covid-19 diakses pada hari selasa, 23 Juni 2021 jam 13.00 wita

\section{Profil Penulis:}

\begin{tabular}{l|l|} 
Muh. Ihsan, Kelahiran Kombng Suli, 23 Januari 1971. \\
Penulis merupakan staf pengajar Sekolah Tinggi Ilmu \\
Tarbiyah Syamsul Ma'arif Bontang dengan bidang keahlian \\
Manajemen Pendidikan. Penelitian penulis lebih fokus pada \\
bidang Pendidikan Agama Islam. Email: \\
iccanrichtv@gmail.com
\end{tabular}

